\title{
PENGARUH L-ASKORBIL-2-FOSFAT MAGNESIUM SEBAGAI SUMBER VITAMIN C TERHADAP PERTUMBUHAN BENIH IKAN GURAMI (Osphronemus gouramy Lac.)
}

\begin{abstract}
Yanti Suryanti
ABSTRAK

Dalam budi daya ikan gurami, pertumbuhannya relatif lambat jika dibandingkan jenis ikan lain. Salah satu upaya untuk meningkatkan pertumbuhan adalah dengan perbaikan kualitas pakan. Tujuan penelitian ini adalah untuk mengetahui pengaruh penambahan I-ascorbyl-2-fosfat$\mathrm{Mg}$ (APM) dalam pakan sebagai sumber vitamin $\mathrm{C}$ terhadap pertumbuhan benih gurami. Bobot awal ikan yang digunakan rata-rata $5,37 \mathrm{~g}$ dengan kepadatan 20 ekor setiap akuarium yang bervolume $100 \mathrm{~L}$. Perlakuan yang digunakan adalah kadar APM yang berbeda yaitu $25 \mathrm{mg}, 50 \mathrm{mg}$, dan $75 \mathrm{mg}$ per $\mathrm{kg}$ pakan dengan kontrol tanpa penambahan APM. Setiap perlakuan terdiri atas 3 ulangan. Penelitian berlangsung selama 3 bulan. Hasil penelitian menunjukkan bahwa penambahan APM lebih dari $75 \mathrm{mg} / \mathrm{kg}$ pakan menghasilkan laju pertumbuhan harian, efisiensi pakan, dan retensi protein berbeda nyata $(P<0,05)$ dengan kontrol. Dengan meningkatnya penambahan APM dalam pakan, maka kandungan vitamin C dalam hati, rasio hidroksiprolina/ prolina, dan L-karnitin otot meningkat.
\end{abstract}

\begin{abstract}
The effect of L-Ascorbyl-2-Phosphate Magnesium as a vitamin $C$ source on growth of gouramy fry. By: Yanti Suryanti

The aim of this experiment was to know addition effect of 1-ascorbyl-2-phosphat-Mg (APM) as a vitamin $C$ source on growth rate of gouramy fry. Average initial body weight of the fish was 5.37 $g$ with stocking density of $20 \mathrm{fish} / 100 \mathrm{~L}$ aquaria. APM was given in different levels i.e. $25 \mathrm{mg}, 50$ $\mathrm{mg}$, and $75 \mathrm{mg}$ per $\mathrm{kg}$ of feed. Feed with no addition of APM was as control. Each treatment had three repilcation feed was given in ad-libitum, with frequency of three times per day. The result of this experiment showed that the addition of APM more than $75 \mathrm{mg} / \mathrm{kg}$ feed resulted significantly $(P<0.05)$ different daily growth rate, feeding efficiency, and protein retention compared to control. Vitamin C in the liver, hidroksiprolina/prolina ratio, and muscle L-karnitin increased in line with the increase of vitamin $C$ level.
\end{abstract}

KEYWORDS: vitamin Clevel, growth, gouramy, fry

\section{PENDAHULUAN}

Sampai saat ini ikan gurami (Osphronemus gouramy Lac.) merupakan komoditas andalan karena mempunyai nilai ekonomis tinggi. Namun dalam budi dayanya ikan gurami mempunyai pertumbuhan yang lambat bila dibandingkan dengan ikan budi daya lainnya seperti ikan mas dan nila. Salah satu cara yang dapat dilakukan dalam mengatasi masalah tersebut adalah dengan perbaikan kualitas pakan.

Untuk menyusun kualitas pakan yang baik bagi ikan diperlukan pengetahuan mengenai kebutuhan nutrisinya, baik makro nutrien maupun mikro nutrien. Salah satu mikro nutrien penting yang dibutuhkan untuk ikan adalah vitamin C. Vitamin C (asam ascorbat; AA) penting bagi ikan karena mempunyai banyak fungsi dalam proses fisiologis tubuh (Masumoto et al., 1991). Beberapa hasil penelitian menunjukkan bahwa AA berpengaruh terhadap kemampuan tubuh dalam mengatasi stres dan pertumbuhan ikan. Peranan AA dalam meningkatkan kemampuan ikan untuk mengatasi stres berkaitan dengan produksi norepineprin dan epineprin dalam biosintesis katekolamin (Mazeaud \& Mazeaud, 1981). Katekolamin berperan memacu proses glukoneogenesis dan glikogenolisis dalam penyediaan glukosa darah untuk dipakai sumber energi (Murray et al., 1999). Selanjutnya energi ini digunakan untuk menahan goncangan fisiologis tubuh akibat stres (Pickering, 1981).

Risiko defisiensi pada ikan sangat besar karena umumnya ikan tidak mampu menyintesis AA di dalam tubuh (He \& Lawrence, 1993). Ketidakmampuan ikan menyintesis vitamin $\mathrm{C}$ disebabkan oleh tidak adanya enzim L-gulunolakton oksidase yang berperanan dalam konversi L-gulunolakton ke bentuk 2-keto-L

\footnotetext{
) Peneliti pada Balai Riset Perikanan Budidaya Air Tawar, Bogor
} 
gulunolakton, sebagai tahap akhir dalam sintesis vitamin C (Chaterje dalam Soliman et al., 1986). Untuk memenuhi kebutuhan tersebut, maka AA harus ada dalam pakan.

Kebutuhan vitamin C guna mencegah defisiensi pada pertumbuhan ikan telah diteliti untuk beberapa spesies. Menurut Kanazawa et al. (1992), penambahan APM sebanyak 3-6 mg per $100 \mathrm{~g}$ pakan memberikan pertumbuhan terbaik dan dapat mencegah terjadinya gejala defisiensi pada ikan yellowtail (Seriola quinqueradiata). Percobaan yang dilakukan Nuranto (1991) menunjukkan bahwa untuk pertumbuhan terbaik ikan lele membutuhkan kadar vitamin C sebanyak $100 \mathrm{mg} / \mathrm{kg}$ pakan, pakan dengan kadar vitamin C sebanyak $25 \mathrm{mg} / \mathrm{kg}$ pakan akan memperlihatkan gejala defisiensi.

Vitamin $\mathrm{C}$ tergolong vitamin yang larut dalam air, bersifat tidak stabil, dan mudah teroksidasi selama proses pembuatan, penyimpanan, dan pemberian pakan. Salah satu sumber AA yang lebih stabil adalah L-ascorbyl-2-phosphate magnesium (APM). Lascorbyl-2-phosphate-magnesium memiliki ketersediaan biologis lebih tinggi dan tahan terhadap oksidasi, sehingga bioaktivitasnya sebagai sumber
AA pada pakan tetap tinggi setelah melalui proses pembuatan pakan (Azwar, 1997).

Oleh karena itu, perlu dilakukan percobaan untuk mengetahui kadar optimal L-ascorbyl-2-fosfat magnesium sebagai sumber vitamin $C$ dalam pakan untuk pertumbuhan benih gurami.

\section{BAHAN DAN METODE}

Penelitian dilakukan di Instalasi Riset Budidaya Ikan Hias Air Tawar, Depok. Ikan uji yang digunakan adalah ikan gurami dengan bobot rata-rata awal individu 5,37 $\mathrm{g}$ dan dipelihara pada kepadatan 20 ekor setiap akuarium berukuran $100 \mathrm{~L}$. Akuarium dilengkapi sistem resirkulasi dan aerasi. Perlakuan yang digunakan adalah kadar APM (L-ascorbyl-2 phosphate magnesium) yang berbeda yaitu $25 \mathrm{mg}, 50 \mathrm{mg}$, dan 75 mg per kg pakan dengan kontrol tanpa penambahan APM. APM dicampur dengan vitamin lain yang kemudian diaduk dengan bahan pakan lain. Komposisi bahan pakan yang digunakan disajikan pada Tabel 1. Pakan diberikan pada ikan sampai kenyang (atsatiation) dengan frekuensi pemberian tiga kali sehari. Agar lingkungan pemeliharaan bersih dilakukan

Tabel 1. Komposisi bahan baku pakan yang digunakan dalam percobaan

Table 1. Composition of feed ingredients used in the experiment

\begin{tabular}{lcccc}
\hline \multirow{2}{*}{$\begin{array}{c}\text { Bahan baku } \\
\text { Ingredients }\end{array}$} & \multicolumn{5}{c}{ Kadar APM (mg/kg pakan) } \\
\cline { 2 - 5 } & $\mathbf{A P M}$ level (mg/kg feed) \\
\cline { 2 - 5 } & 29.33 & 29.33 & 29.33 & 29.33 \\
\hline Tepung ikan (Fish meal) & 25.43 & 25.43 & 25.43 & 25.43 \\
Bungkil kedelai (Soybean meal) & 35 & 35 & 35 & 35 \\
Terigu (Wheat) & 2 & 2 & 2 & 2 \\
Campuran vitamin (tanpa Vit. C)* & & & & \\
Vitamin mix (without Vit. C) & 1 & 1 & 1 & 1 \\
Mineral mix* (Mineral mix) & 2 & 2 & 2 & 2 \\
Minyak jagung (Corn oil) & 2 & 2 & 2 & 2 \\
Minyak ikan (Fish oil) & 0 & 0.03 & 0.05 & 0.08 \\
L-ascorbyl-2-phosphat-Mg & & & & \\
L-ascorbyl-2-phosphat-Mg & 3.24 & 3.23 & 3.19 & 3.17 \\
a-selulosa (a-celulose) & & & & \\
\hline
\end{tabular}

Analisis proksimat :

Proximate analysis :

$\begin{array}{llr}\text { Protein (Crude protein (\%)) } & : & 34.74 \\ \text { Lemak (Lipid) (\%) } & : & 8.32 \\ \text { BETN (Nitrogen free extract) } & : & 41.67 \\ \text { Kadar air (Moisture }(\%)) & : & 6.90 \\ \text { Energi (kkal/g pakan) } & : 2,757.87 \\ \text { Energy (kcal/g feed) } & \end{array}$

* Berdasarkan Sandra (2002) 
penyiponan kotoran setiap hari. Penimbangan sampel bobot tubuh dilakukan setiap 14 hari sekali.

Parameter yang diukur meliputi laju pertumbuhan harian, efisiensi pakan, retensi protein, dan lemak serta hepatosomatik indeks.

Parameter biokimia yang dianalisis terdiri atas kadar vitamin C hati, L-karnitin otot, hidroksiprolina, dan prolina tubuh. Analisis kadar vitamin C hati dilakukan pada awal dan akhir percobaan mengikuti prosedur Schuep et al. (1994) dalam Azwar (1997) dengan menggunakan high performance liquid chromatography (HPLC). Sedangkan analisis kadar hidroksiprolina dan prolina tubuh ikan pada awal dan akhir percobaan mengikuti prosedur yang dilakukan Sandra (2002) dengan menggunakan spektrofotometer. Analisis Lkarnitin otot dilakukan pada akhir percobaan mengikuti prosedur Miyasaki et al. (1994) dalam Sandra (2002) dengan menggunakan HPLC. Analisis proksimat tubuh ikan dilakukan pada awal dan akhir percobaan.

\section{HASIL DAN BAHASAN}

Hasil pengamatan terhadap bobot individu ikan (Gambar 1) memperlihatkan bahwa bobot rata-rata individu pada ikan yang diberi pakan tanpa penambahan APM adalah terendah, dan tertinggi pada kadar APM $75 \mathrm{mg} / \mathrm{kg}$ pakan.

Laju pertumbuhan harian benih ikan gurami yang diberi pakan dengan penambahan APM sampai kadar $50 \mathrm{mg} / \mathrm{kg}$ pakan tidak berbeda nyata $(P>0,05)$ dibandingkan tanpa APM. Sedangkan laju pertumbuhan harian ikan yang diberi APM pada kadar $75 \mathrm{mg} / \mathrm{kg}$ pakan berbeda nyata $(P<0,05)$ dengan tanpa APM. Hal ini selaras dengan data efisiensi pakan dan retensi protein yang dihasilkan (Tabel 2).

Pertumbuhan merupakan pertambahan bobot ikan yang ditentukan oleh perkembangan sel jaringan dan tulang. Pembentukan matriks, tulang, kulit, dan jaringan ikat memerlukan kolagen yang bahan dasarnya adalah prokolagen. Jika vitamin C tersedia dalam jumlah cukup, pembentukan kolagen akan normal dan ini akan mendukung pertumbuhan dan akhirnya efisiensi pemanfaatan pakan meningkat. Kolagen ini merupakan komponen protein yang terbanyak, yaitu sekitar $25 \%--30 \%$ dari total protein tubuh (Combs, 1992). Berdasarkan kedua peran vitamin C tersebut, ikan dapat memanfaatkan protein dan melakukan sintesis kolagen dengan baik, sehingga pada akhirnya tercapai pertumbuhan optimal, seperti yang telah diteliti oleh Jusadi et al. (2000) terhadap ikan gurami ukuran $\pm 0,78 \mathrm{~g}$.

Peningkatan pertumbuhan pada perlakuan APM $75 \mathrm{mg} / \mathrm{kg}$ pakan berkaitan pula dengan retensi protein. Hal ini berkorelasi dengan peran vitamin $\mathrm{C}$ dalam tubuh, yaitu sebagai kofaktor reaksi hidroksilase asam amino tryptopan, tyrosin, lisin, penilalanin, dan prolin (Tacon, 1991), sehingga dengan adanya vitamin C ikan akan memanfaatkan protein lebih efisien untuk pertumbuhan jaringan.

Menurut Ji et al. (1996), peningkatan karnitin pada tubuh ikan salmon dapat meningkatkan sintesis protein. Terlihat jelas pada Tabel 2, seiring meningkatnya karnitin otot pada kadar APM 75 mg/kg pakan, juga meningkatkan retensi protein. Sedangkan untuk retensi lemak secara statistik tidak berbeda nyata $(P>0,05)$. Hal ini disebabkan lemak yang dimanfaatkan digunakan sebagai energi. Jadi dari uraian di atas untuk menghasilkan pertumbuhan benih gurami yang optimal diperlukan penambahan APM dalam pakan lebih dari $75 \mathrm{mg} / \mathrm{kg}$ pakan.

Hati merupakan organ yang memiliki aktivitas metabolisme terbesar di tubuh dan juga dapat sebagai tempat akumulasi nutrien yang disintesis. Dari data hepatosomatik indeks bahwa dengan bertambahnya kadar vitamin $\mathrm{C}$, hepatosomatik indeks semakin meningkat. Hal ini diduga penambahan vitamin $\mathrm{C}$ dalam pakan akan menstimulasi aktivitas lipogenik dalam hati. Percobaan yang dilakukan oleh Kosutarak et al. (1995) terhadap benih ikan Pagurus mayur menghasilkan bahwa pengurangan askorbil fosfat magnesium menyebabkan rendahnya kandungan lipida trigliserida pada hati dan daging. Selanjutnya kadar lipida hati ikan yang menerima pakan dengan suplementasi askorbil fosfat magnesium lebih tinggi dibandingkan perlakuan kontrol.

Dari penampilan luar ikan antara yang diberi tambahan vitamin $\mathrm{C}$ dan tanpa vitamin $\mathrm{C}$ tidak ada kelainan kecuali dari kecepatan tumbuhnya. Penambahan vitamin C (APM) dalam pakan berpengaruh terhadap kandungan vitamin $\mathrm{C}$ dalam hati, rasio hidroksiprolina/prolina, total lemak tubuh, dan L-karnitin (Tabel 3).

Dari Tabel 2 terlihat bahwa kadar vitamin $\mathrm{C}$ hati meningkat dengan bertambahnya kandungan vitamin C dalam pakan. Menurut Agrawal \& Mahajan (1980), bahwa tingginya kandungan vitamin $\mathrm{C}$ pada hati berkaitan antara lain dengan fungsinya dalam reaksi redoks potensial NADH dan metabolisme kolesterol membentuk asam empedu. Sedangkan Kosutarak et al. (1995) mengemukakan bahwa adanya vitamin C dalam hati berperan pula dalam metabolisme lipida. Kanazawa et al. (1992) dan El Naggar \& Lovell (1991) masing-masing mengamati ikan ekor kuning dan ikan lele mencatat pula bahwa suplementasi askorbil fosfat magnesium cepat meningkatkan vitamin $\mathrm{C}$ dalam hati, namun mempunyai batas maksimum.

Dengan meningkatnya kadar vitamin C dalam pakan, rasio hidroksiprolina/prolina yang dihasilkan 


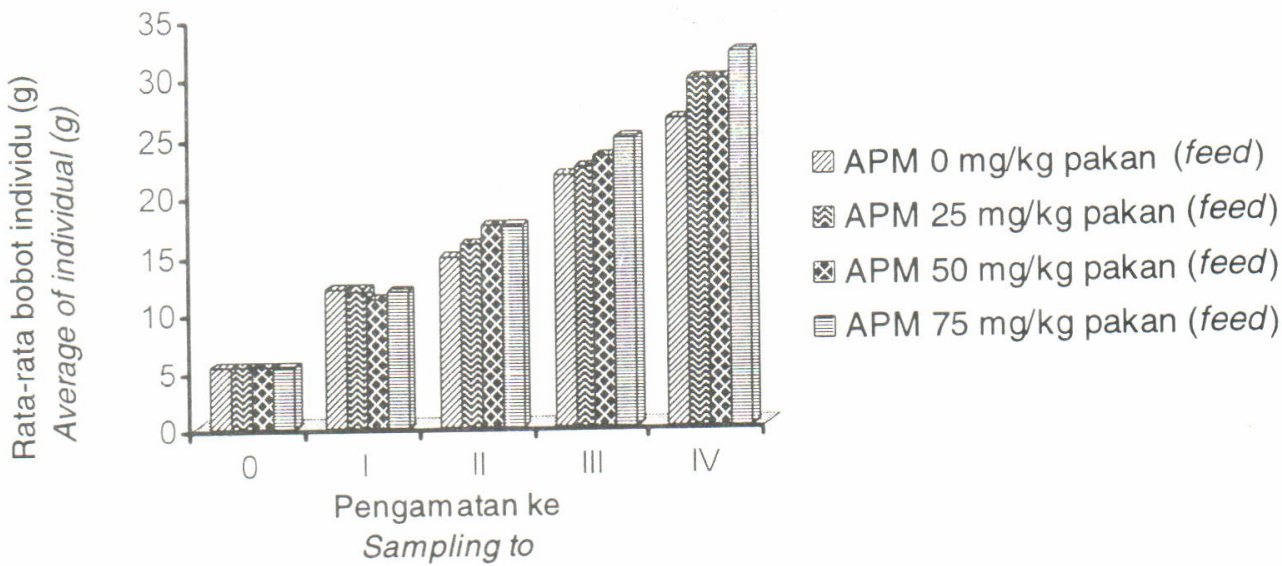

Gambar 1. Rata-rata bobot individu setiap sampling selama penelitian

Figure 1. Average of individual body weight at each sampling during the experiment

Tabel2. Performansi pertumbuhan benih gurami selama penelitian

Table 2. Growth performance of gouramy fry during the experiment

\begin{tabular}{|c|c|c|c|c|}
\hline \multirow{2}{*}{$\begin{array}{l}\text { Parameter } \\
\text { Parameters }\end{array}$} & \multicolumn{4}{|c|}{ Kadar APM (mg/kg pakan) } \\
\hline & 0 & 25 & 50 & 75 \\
\hline $\begin{array}{l}\text { Laju pertumbuhan harian } \\
\text { Daily growth rate (\%) }\end{array}$ & $2.86 \pm 0.21^{a}$ & $3.07 \pm 0.31^{\mathrm{ab}}$ & $3.10 \pm 0.24^{\mathrm{ab}}$ & $3.22 \pm 0.13 b^{c}$ \\
\hline $\begin{array}{l}\text { Efisiensi pakan }(\%) \\
\text { Feed efficiency }(\%)\end{array}$ & $50.56 \pm 3.70^{\mathrm{a}}$ & $56.66 \pm 11.21^{\mathrm{ab}}$ & $58.43 \pm 4.68^{\mathrm{ab}}$ & $62.76 \pm 7.28^{\mathrm{bc}}$ \\
\hline $\begin{array}{l}\text { Retensi protein }(\%) \\
\text { Protein retention }(\%)\end{array}$ & $22.66 \pm 2.48^{\mathrm{a}}$ & $25.54 \pm 4.69^{\mathrm{ab}}$ & $28.06 \pm 3.59^{\mathrm{ab}}$ & $28.82 \pm 2.47^{b c}$ \\
\hline $\begin{array}{l}\text { Retensi lemak (\%) } \\
\text { Fat retention (\%) }\end{array}$ & $55.63 \pm 5.01^{a}$ & $56.59 \pm 5.61^{a}$ & $56.61 \pm 6.64^{\mathrm{a}}$ & $58.34 \pm 3.81^{a}$ \\
\hline $\begin{array}{l}\text { Hepatosomatik indeks (\%) } \\
\text { Index hepatosomatic (\%) }\end{array}$ & $1.84 \pm 0.29^{\mathrm{a}}$ & $2.42 \pm 0.54^{\mathrm{a}}$ & $2.88 \pm 0.24^{a}$ & $2.91 \pm 0.53^{\mathrm{a}}$ \\
\hline
\end{tabular}

Angka dalam kolom yang diikuti huruf superskrip yang sama tidak berbeda nyata $(P>0,05)$

Values in columns with the same superscript are not significantly different $(P>0.05)$

meningkat. Hal ini mengindikasikan peran vitamin C sebagai agen pereduksi fisiologis yang spesifik pada sintesis prokolagen dalam pembentukan kolagen di tubuh ikan gurami. Menurut Kosutarak et al. (1995), vitamin $\mathrm{C}$ berperan dalam pembentukan kolagen. Hidroksiprolina (prokolagen) merupakan komponen pembentuk kolagen. Pembentukan kolagen penting untuk pertumbuhan normal ikan karena kolagen merupakan komponen utama matriks tulang, kulit, dan jaringan ikat guna menopang integritas struktur tubuh, terutama pada hewan yang masih muda (Linder, 1992). Terhambatnya pembentukan kolagen menyebabkan terjadinya pertumbuhan tulang yang tidak sempurna (Kosutarak et al., 1995). Hasil penelitian Sato et al. (1991) menunjukkan bahwa ikan trout berukuran 650 g/ekor yang diberi pakan dengan penambahan vita- min C dalam bentuk L-askorbil-2-fosfate magnesium dan asam askorbat masing-masing 100, 200, 500, dan $2.000 \mathrm{mg} / \mathrm{kg}$ pakan selama 15 minggu menghasilkan rasio hidroksiprolin/prolin di kulit dan tulang masing-masing 0,65 ; sedang ikan yang menerima pakan tanpa penambahan vitamin C menghasilkan rasio $\mathrm{Hp} / \mathrm{p}$ sebesar 0,48 yang menyebabkan pertumbuhan tulang tidak sempurna.

Pada percobaan ini pada kadar APM $25 \mathrm{mg} / \mathrm{kg}$ pakan total lemak tubuh meningkat. Hal ini menunjukkan adanya peran vitamin $\mathrm{C}$ dalam penyerapan lemak pakan dan juga mengindikasikan perannya sebagai antioksidan, sehingga keberadaan lemak di tubuh dapat dipertahankan.

Dengan penambahan kadar APM lebih dari $25 \mathrm{mg} /$ $\mathrm{kg}$ pakan terjadi penurunan total lemak tubuh. Menurut 
Tabel 3. Kandungan vitamin C hati, rasio hidroksiprolin/prolin, total lemak, dan L-karnitin otot tubuh gurami Table 3. Vitamin C content in the liver, hydroxiprolina/prolina ratio, fat total, and in the muscle L-carnitine of gouramy body

\begin{tabular}{|c|c|c|c|c|c|}
\hline \multirow{2}{*}{$\begin{array}{l}\text { Parameter } \\
\text { Parameters }\end{array}$} & \multirow{2}{*}{$\begin{array}{l}\text { Awal } \\
\text { Initial }\end{array}$} & \multicolumn{4}{|c|}{$\begin{array}{c}\text { Kadar APM (mg/kg pakan) } \\
\text { APM level (mg/kg feed) }\end{array}$} \\
\hline & & 0 & 25 & 50 & 75 \\
\hline $\begin{array}{l}\text { Vitamin } C \text { hati }(\mathrm{mg} / \mathrm{L}) \\
\text { Vitamin } C \text { in liver }(m g / L)\end{array}$ & 225.25 & 334.42 & 363.52 & 449.01 & 483.20 \\
\hline $\begin{array}{l}\text { Rasio hidroksiprolina/Prolina } \\
\text { Hydroxiprolin/prolin Ratio (\%) }\end{array}$ & 60.51 & 67.94 & 68.38 & 69.16 & 71.71 \\
\hline $\begin{array}{l}\text { Total lemak tubuh }(\%) \\
\text { Body fat total }(\%)\end{array}$ & 14.79 & 28.44 & 28.57 & 25.42 & 25.79 \\
\hline $\begin{array}{l}\text { L-karnitin otot (\%) } \\
\text { L-carnitine (\%) }\end{array}$ & - & 200.26 & 235.31 & 241.52 & 266.47 \\
\hline
\end{tabular}

Murray et al. (1999), vitamin C berperan dalam pembentukan asam empedu. Asam empedu berfungsi untuk menyerap lemak dan vitamin yang larut lemak dari pakan (Muchtadi et al., 1993). Jadi penurunan total lemak tubuh tersebut menyebabkan diduga pembentukan asam empedu berkurang karena terjadinya penurunan kolesterol tubuh akibat adanya peningkatan metabolisme lemak. Hal ini sama dengan hasil penelitian yang dilakukan oleh Sandra (2002) terhadap ikan baung, bahwa penambahan kadar APM lebih dari $25 \mathrm{mg} / \mathrm{kg}$ pakan menyebabkan penurunan total lemak pakan.

Peningkatan kadar vitamin $C$ dalam percobaan ini menghasilkan L-karnitin otot meningkat. Hal ini sesuai dengan pendapat Miyasaki et al. (1995) bahwa vitamin $\mathrm{C}$ dapat mempengaruhi metabolisme lipid dan Lkarnitin tubuh. Vitamin $\mathrm{C}$ berperan dalam reaksi enzim hidroksilase mitokondrial dan hidroksilase sitosolik pada tahap II dan V jalur pembentukan karnitin (Feller \& Rudman, 1988). Dalam tubuh, karnitin berperan mentranspor asam lemak rantai panjang dari sitosol ke mitokondria untuk dioksidasi menjadi energi (Murray et al., 1999). Dengan demikian kadar vitamin $C$ dalam tubuh, optimal dan ketersediaan karnitin sebagai carrier cukup, sehingga meningkatkan efisiensi penggunaan energi lemak tubuh. Penambahan vitamin $\mathrm{C}$ dalam pakan rainbow trout dapat meningkatkan kadar L-karnitin di otot dan hati (Miyasaki et al., 1995).

Selama penelitian ( 3 bulan), sintasan yang dihasilkan antara $95 \%--100 \%$, dan kualitas air dalam kisaran normal bagi kehidupan ikan.

\section{KESIMPULAN}

Dari hasil penelitian dapat disimpulkan bahwa penambahan I-ascorbyl-2-phosphat-Mg (sebagai sumber vitamin C) lebih dari $75 \mathrm{mg} / \mathrm{kg}$ pakan menghasilkan pertumbuhan lebih baik untuk benih gurami.

\section{DAFTAR PUSTAKA}

Agrawal, N.K. and C.K. Mahajan. 1980. Comparative tissue ascorbil acid studies in fish. J. Fish Biol., 17: 135--141.

Azwar, Z.I. 1997. Pengaruh Askorbil Fosfat Magnesium sebagai Sumber Vitamin C terhadap Perkembangan Ovarium dan Penampilan Larva Ikan Nila (Oreochromis sp.). Disertasi, Program Pascasarjana, Institut Pertanian Bogor. 180 pp.

Combs, G.F. 1992. The Vitamin Fundamental Aspects in Nutrition and Health. Academic Press, London 528 $\mathrm{pp}$.

El Naggar, G.O. and R.T. Lovell. 1991. Effect of source and dietary concentration of ascorbic acid tissue concentrations of ascorbic acid in channel catfish. $J$. World Aquaculture Soc., 22(44): 159--165.

Feller, A.G. and Rudman, D. 1988. Role of carnitine in human nutrition. J. Nutr. 188:541--547.

He, H. and Lawrence A.L. 1993. Vitamin C requirement of the shrimp Penaeus vannamei. Aquaculture, 114:305--317.

Ji, H., Bradley T.M. and Tremblay G.C. 1996. Atlantic salmon (Salmo salar) fed carnitine exhibit altered intermediary metabolism and reduced tissue lipid, but no change in growth rate. J. Nutr. 126:1937-1950.

Jusadi, D., Abdul Muis, dan Ing Mokoginta. 2000. Kebutuhan vitamin $C$ benih ikan gurame Osphronemus gouramy. J. IImu-llmu Perairan dan Perikanan Indonesia, VII(1): 17--25.

Kanazawa, A., S. Teshima, S. Koshi, M. Higashi, and S. Itoh. 1992. Effect of L-ascorbyl-2-phosphate-Mg on the yellowtail (Seriola quinquenradiata) as a vitamin C source. J. Nippon Suisan Gakkaishi 58(2):337-340.

Kosutarak, P., A. Kanazawa, S. Teshima, and S. Koshio. 1995. Interaction of L-ascorbyl-2-phosphate Mg and 
oxidized fish oil on red sea bream juveniles. Fish. Sci. 61 (4): 696--702.

Lovell, R.T. 1984. Ascorbic acid metabolism in fish. Proc. Ascorbic Acid in Domestic Animal. The Royal Danish Agricultural Soc. Copenhagen. p. 206--212.

Masumoto, T., Hosokawa H., Shimeno S. 1991. Ascorbic acids role in aquaculture nutrition in Proccedings of the Aquaculture Feed Processing and Nutrition Workshop. Editing by Akiyama D.M., Tan R.K.H. Thailand and Indonesia September 19--25, 1991. American Soybean Association, Singapore, p. 42--48.

Mazeaud, M. and Mazeaud. 1981. Adrenergic responses to stress in fish. In Pickering AD (Eds.) Stress and Fish. Academic Press, London, New York, Toronto, Sydney. San Francisco. p. 49--68.

Muchtadi, D., Palupi N.S., dan Astawan, M. 1993. Metabolisme Zat Gizi: Sumber, Fungsi, dan Kebutuhan bagi Tubuh Manusia. Jilid II. Pustaka sinar harapan. Jakarta.

Miyasaki, T., M. Sato, R. Yoshinaka, and M. Sakaguchi. 1995. Effect of vitamin C on lipid and carnitine metabolism rainbow trout. Fish. Sci., 61(3):501--506.

Murray, R.K., D.K. Granner, P. A. Mayes, and V.W. Rodwell. 1999. Biokimia Harper. Andry Hartono, alih bahasa. Edisi 24 Jakarta; Penerbit Buku Kedokteran EGC: $617--632$.

Nuranto A. 1991. Pengaruh Vitamin C terhadap Pertumbuhan Ikan Lele (Clarias batrachus L.).
Tesis, Program Pascasarjana, Institut Pertanian Bogor. 73 pp.

Pickering, A.D. 1981. The concept of biological stress. In Pickering AD (Eds.) Stress and Fish. Academic Press, London, New york, Toronto, Sydney. San Francisco. p. 1--7.

Sato, M.Y., Hatano, and R. Yoshinaka. 1991. L-ascorbil2-sulphate as a dietary vitamin $C$ source for rainbow trout, Oncorhynchus mykiss. Nippon Suisan Gakkaishi 57(4):717--721.

Soliman, A.K., K. Jauncey, and R.J. Robert. 1986. The effect of dietary ascorbic acid suplementation on hatchability, survival rate and fry performance in Oreochromis mossambicus (Peter). Aquaculture, 59:197--208.

Sandra, H. 2002. Pengaruh Kadar Vitamin C Pakan Bentuk L-askorbil-2-fosfat Magnesium yang Berbeda terhadap Kemampuan Tubuh Mengatasi Stres dan Pertumbuhan Ikan Baung (Mystus nemurus C.V.). Tesis. Program Pascasarjana Institut Pertanian Bogor. 76 pp.

Tacon, A.G.J. 1991. Vitamin nutrition in shrimp and fish. Dalam Akiyama, D.M. dan R.K.H. Tan (Eds.) Proceeding of the Aquaculture Feed Processing and Nutrition Workshop, American Soybean Association, Singapura. p. 10--41 